\title{
p53 protein subcellular localization and apoptosis in rodent corneal epithelium cell culture following ultraviolet irradiation
}

\author{
YEVGENY TENDLER ${ }^{1}$, RUSSELL POKROY ${ }^{2}$, ALEX PANSHIN ${ }^{3}$ and GARY WEISINGER ${ }^{4}$ \\ ${ }^{1}$ Department of Clinical Biochemistry, Rambam Medical Center, Haifa; ${ }^{2}$ Department of Ophthalmology, \\ Assaf Harofeh Medical Center, Be'er Ya'akov; ${ }^{3}$ Unit of Molecular Virology, Division of Avian Diseases, \\ Kimron Veterinary Institute, Beit Dagan; ${ }^{4}$ Department of Endocrinology, Sourasky Medical Center, Tel Aviv, Israel
}

Received October 25, 2012; Accepted December 3, 2012

DOI: 10.3892/ijmm.2013.1247

\begin{abstract}
The tumor-suppressor gene p53 encodes a phosphoprotein involved in the control of cell growth. p53 expression and function have been documented in malignancy, apoptosis and the aging processes. Recently, p53 has been mapped and characterized in the normal cornea across different species. In the present study, high levels of cytoplasmic p53 protein were noted in normal primary corneal epithelium cultures by immunohistochemistry and western blot analysis. Following ultraviolet (UV) irradiation, the level of cytoplasmic p53 protein expression was increased beginning from $30 \mathrm{~min}$ and lasting until $6 \mathrm{~h}$ post-irradiation and then returned close to control levels by $24 \mathrm{~h}$. Cytoplasmic p53 phosphorylation was detected from 30 min following UV treatment until $6 \mathrm{~h}$ postirradiation. p53 protein became apparent in the nucleus in a fraction of these cultured cells beginning 30 min following UV irradiation and was still present $24 \mathrm{~h}$ later. We also found that p53 colocalized with mitochondria $2 \mathrm{~h}$ following UV irradiation in some of the cells and remained there up to $24 \mathrm{~h}$. As the expression levels of p53 transcription following UV irradiation were not significantly altered, the increase in cytoplasmic p53 protein expression may be conditional only upon posttranslational stabilization. We also observed that the apoptotic index increased following UV irradiation in the same time frame as the p53 nuclear transfer and was partially suppressed by pifithrin- $\alpha$, which is a reversible inhibitor of p53-mediated apoptosis and p53-dependent gene transcription. The present study offers new evidence suggesting that cytoplasmic p53 in rodent corneal epithelium is functionally active.
\end{abstract}

\section{Introduction}

The p53 gene is a well-defined tumor-suppressor gene. The gene produces a $53-\mathrm{kDa}$ phosphoprotein that was first char-

Correspondence to: Dr Yevgeny Tendler, Department of Clinical Biochemistry, Rambam Medical Center, Haifa, Israel

E-mail: tendler@tx.technion.ac.il

Key words: p53, apoptosis, cytoplasmic localization, corneal epithelium, immunoblotting, immunohistochemistry acterized as the major cellular protein associated with the $\mathrm{T}$ antigen encoded by simian virus 40 (SV40), a small DNA virus (1-3). SV40 and other oncogenic viruses target p53 in order to induce cell proliferation, thus increasing the number of cells carrying their genomes. p53 plays a role in many abnormal types of cell proliferation, in apoptosis in response to DNA injury, in the prevention of replication of genomes that have suffered DNA damage $(2,4-9)$, in the inhibition of tumor angiogenesis (10), and in embryogenesis (11). In general, the target genes of p53 can be grouped into categories of biological activities that include apoptosis, growth arrest, DNA repair, checkpoint responses and balancing of aerobic respiration and glycolysis (12).

Apart from the transcription-dependent induction of apoptosis, p53 also induces apoptosis through a mitochondrial pathway. In this pathway, p53 binds to the outer mitochondrial membrane, induces its permeabilization, and forms complexes with the protective $\mathrm{Bcl} X \mathrm{~L}$ and $\mathrm{Bcl}-2$ proteins. The binding of p53 to these factors triggers cytochrome c release and caspase activation (13-16).

Pifithrin- $\alpha$ is a reversible inhibitor of p53-mediated apoptosis and p53-dependent gene transcription. Notably, transcriptional-dependent apoptosis is repressed by pifithrin, while mitochondrial-dependent apoptosis is not repressed (17).

We previously demonstrated and characterized p53 expression in the rodent corneal epithelium (18-20). Others have found that UV irradiation was able to induce the p53 protein (8) and p53-dependent apoptosis in the corneal epithelium (21-23). However, its causative contribution to apoptosis has yet to be determined. In the present study we examined changes in apoptosis and p53 expression and functional activity in rodent corneal epithelium in response to UV irradiation.

\section{Materials and methods}

Animals. C57BL/6 mice were obtained from the Animal Facility of Haifa Technion. Eyes of animals were enucleated after sacrifice by $\mathrm{CO}_{2}$ narcosis. The use of animals adhered to the ethical guidelines of and was supervised by the Technion Animal Welfare Committee.

Cell culture. In order to investigate corneal epithelial cells derived from the ocular surface, we used a corneal epithelial 
cell culture system, as previously described (24). Outgrowing cells from corneal explants formed in the suspension epithelial cell culture. These cells were grown in RPMI-1640 medium supplemented with $10 \%$ fetal bovine serum, $2 \mathrm{mmol} / \mathrm{l}$ of L-glutamine, MEM-Eagle vitamin solution concentrate $(100 \mathrm{x}), 50 \mu \mathrm{g} / \mathrm{ml}$ penicillin and $50 \mu \mathrm{g} / \mathrm{ml}$ streptomycin (Beit Haemek, Israel).

Immunohistochemistry. p53 immunostaining was performed using the monoclonal antibodies: Mab-248, which binds to an N-terminal or central epitope of the p53 molecule (25-27); and Mab-421, which recognizes a C-terminal epitope of the p53 protein $(26,28)$ (both a kind gift from Professor V. Rotter, Weizmann Institute of Science, Rehovot, Israel) and a monoclonal antibody against phosphorylated Ser15 of the p53 protein (Cell Signaling Technology). Immunostaining with these antibodies was performed overnight at $4^{\circ} \mathrm{C}$ in a humidity chamber, followed by the avidin-biotin secondary antibody staining technique, in which a biotinylated secondary antibody reacts with several peroxidase-conjugated streptavidin molecules (Dako Labs 2 kit; DakoCytomation, Glostrup, Denmark). Alternatively, the HistoMouse ${ }^{\mathrm{TM}}-\mathrm{Max}$ kit (Zymed Laboratories, Inc., South San Francisco, CA, USA) was used. All control samples were processed in the absence of the primary antibody. The slides were washed, mounted with an aqueous mounting medium and photographed within a few hours under a digital microscope camera (Zeiss Axioscope 2 with image processing software Image-Pro Plus version 6). Light intensity and contrast were standardized for a respective culture with an appropriate control.

Apoptotic index determination. On-slide in situ terminal deoxynucleotidyl transferase-mediated dUTP-biotin nick endlabeled (TUNEL) assay was used. The apoptotic index (AI) was determined using the ApopTag marker (Oncor, Inc., Gaithersburg, MD, USA) and was calculated as the percentage of TUNEL-positive cells per 1,000 cells, according to a previously described procedure (29).

Fluorescence staining of p53 immunoreactive protein. Twenty-four hours after plating, cells were incubated with $200 \mathrm{nmol} / 1$ of MitoTracker Red 580 (Molecular Probes, Eugene, OR, USA) in culture medium for $40 \mathrm{~min}$, after which the dye was removed, and cells were treated with or without $15 \mu \mathrm{M}$ of pifithrin- $\alpha$ (Sigma, St. Louis, MO, USA) for $2 \mathrm{~h}$. The cells were then irradiated with a UV lamp (312 nm) at $150 \mathrm{~mJ} / \mathrm{cm}^{2}$. The Petri dish was placed $15 \mathrm{~cm}$ above a UV light source $(4 \times 6 \mathrm{~W}, 312-\mathrm{nm}$ tube, power $50 \mathrm{~W}$, TFP-10M, Vilber Lourmant, Torcy, France) for $5 \mathrm{~min}$. The UV dosimetry was performed using a UV light meter (YK-34UV; Lutron Electronic, Taiwan). Following UV irradiation, cells were fixed in absolute methanol for $10 \mathrm{~min}$, placed on a slide and dried. After rinsing with cold PBS ( $\mathrm{pH}$ 7.4) cells were permeabilized with $0.5 \%$ Triton $\mathrm{X}-100$ for $10 \mathrm{~min}$ at room temperature (RT). After blocking, the anti-p53 antibody (Mab-421) was added (without dilution) and incubated at RT for $2 \mathrm{~h}$ followed by incubation with anti-mouse IgG-FITC (Sigma) (1:128 dilution) for $1 \mathrm{~h}$. After removal of the antibodies, the cells were rinsed with PBS and mounted with UltraMount (Lab Vision, UK). Fluorescence was immediately observed using either an Axioscop 2 or Leica laser scanning confocal microscope (Bensheim, Germany).

Protein determination. Protein was quantitated by the method of Bradford (30) using bovine serum albumin as a standard. In brief, unknown protein concentrations were determined spectrophotometically $(595 \mathrm{~nm})$, following the binding of the dye, Coomassie Brilliant Blue, to both unknown protein preparations and predetermined standard concentrations of bovine serum albumin, and their optical densities were compared.

Western blot analysis. Ocular cell protein extracts were prepared in lysis buffer (1\% Triton X-100 and 0.1\% SDS in PBS), as previously described (20). Equal amounts of protein derived from the epithelial cell cultures were compared to each other by western blot analysis, following resolution of protein samples (50 $\mu \mathrm{g} /$ well) by standard denaturing SDS $7.5 \%$ polyacrylamide gel electrophoresis, using standard conditions (31). Proteins were transferred to nitrocellulose membranes (Schleicher and Schuell Bioscience GmbH, Germany), as previously described (20). Bovine serum albumin blocked (BSA, $2 \%$ in TBS-T) and blotted nitrocellulose membranes were subjected to western blot analysis using the Mab-248 antibody. This was followed by incubation with rabbit anti-mouse IgG (whole-molecule) conjugated to horseradish peroxidase (HPR) (Sigma) at a dilution of 1:1,000 for $1 \mathrm{~h}$ at RT. Between incubations, the blots were washed three times for $10 \mathrm{~min} /$ wash with $1 \mathrm{X}$ PBS containing $0.05 \%$ Tween-20. Enhanced chemiluminescence (ECL) substrates to develop the results (Amersham, Buckinghamshire, UK) and Sea-Blue protein molecular weight markers (Novartis, San Diego, Ca, USA) were used on each gel. Fifty micrograms of p53-M clone 314 cell extract (a kind gift from Professor V. Rotter, Weizman Institute) (32) was used as a p53-positive control (p53-M), while $50 \mu \mathrm{g}$ of BSA was used as a negative control (NC).

Quantitative p53 mRNA determination by real-time $P C R$. Total RNA from mouse corneal epithelium cells was extracted with the MasterPure RNA Purification kit (Epicentre Biotechnologies, Madison, WI, USA). Total RNA concentrations were determined spectrophotometrically by measuring the absorbance at $260 \mathrm{~nm}$. cDNA was generated from $2 \mu \mathrm{g}$ of total RNA using Verso ${ }^{\mathrm{TM}}$ reverse transcriptase$\mathrm{RT}$ and random primers (Verso ${ }^{\mathrm{TM}}$ cDNA kit; Thermo Scientific, Surrey, UK), according to the manufacturer's instructions. Primers and probes for $\beta$-actin and mouse p53 genes were designed by Primer Design Ltd., Southampton, UK (Table I). p53 mRNA production was measured by quantitative real-time PCR by means of Rotor-Gene 6000 (Corbett Life Science/Qiagen) amplification with ABsolute Blue Mix (Thermo Scientific).

Statistical analysis. Data are reported as means \pm SEM and $\mathrm{P}<0.05$ was considered to indicate a statistically significant result. Groups were compared by ANOVA with Student-Newman-Keuls post hoc analysis or Kruskal-Wallis nonparametric ANOVA, with Dunn's post hoc analysis, as appropriate. 
Table I. Quantitative real-time PCR conditions.

\begin{tabular}{|c|c|c|c|c|}
\hline mRNA & $\begin{array}{l}\text { Denaturation parameters } \\
\text { (temperature/time) }\end{array}$ & $\begin{array}{c}\text { Data collection } \\
\text { (temperature/time) }\end{array}$ & $\begin{array}{c}\text { Extension } \\
\text { (temperature/time) }\end{array}$ & $\begin{array}{l}\text { No. } \\
\text { of cycles }\end{array}$ \\
\hline $\begin{array}{l}\text { Mus musculus } \mathrm{p} 53 \\
\text { Accession: M13873 } \\
\text { (sequences after alignments) }\end{array}$ & $95^{\circ} \mathrm{C} / 15 \mathrm{sec}$ & $50^{\circ} \mathrm{C} / 30 \mathrm{sec}$ & $72^{\circ} \mathrm{C} / 15 \mathrm{sec}$ & 30 \\
\hline $\begin{array}{l}\text { Sense primer } \\
\text { Antisense primer } \\
\text { Probe }\end{array}$ & \multicolumn{4}{|c|}{$\begin{array}{l}\text { GAACCGCCGACCTATCCTTA } \\
\text { GCACAAACACGAACCTCAAA } \\
\text { cagtggCTGTCCCGTCCCAGAAGGTTCCCACTG }\end{array}$} \\
\hline
\end{tabular}

Table II. p53 expression and apoptosis following UV-irradiation in corneal epithelial cell cultures.

\begin{tabular}{lcccc}
\hline Epithelial cell culture & Pifithrin & $\begin{array}{c}\text { Staining with } \\
\text { Mab-421 }\end{array}$ & $\begin{array}{c}\text { Staining with Mab } \\
\text { phospho-p53, Ser15 }\end{array}$ & $\begin{array}{c}\text { Apoptotic index } \\
\text { (mean } \pm \text { SE) }\end{array}$ \\
\hline Control & + & ++ & - & $5.82 \pm 0.3$ \\
& & ++ & - & $5.21 \pm 0.25$ \\
30 min following UV & + & +++ & ++ & $12.12 \pm 0.63$ \\
& & +++ & ++ & $11.28 \pm 0.55$ \\
2 h following UV & + & ++++ & ++ & $28.0 \pm 1.3$ \\
& + & +++ & ++ & $19.10 \pm 0.96^{\mathrm{a}}$ \\
6 h following UV & + & +++ & ++ & $31.02 \pm 1.53$ \\
& & ++ & - & $20.09 \pm 1.1^{\mathrm{a}}$ \\
& & ++ & - & $25.63 \pm 1.05$ \\
& + & + & $++48 \pm 0.47^{\mathrm{a}}$ \\
\hline
\end{tabular}

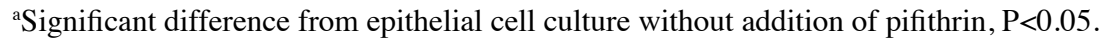

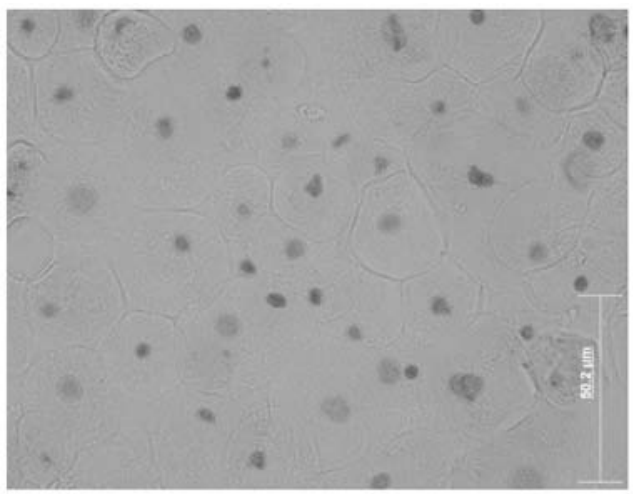

Figure 1. Outgrowing cells from corneal explants formed in the epithelial cell culture. Magnification, $\mathrm{x} 400$.

\section{Results}

p53 immunostaining and subcellular localization in the corneal epithelium after UV exposure (in vitro). In order to investigate corneal epithelial cells on the ocular surface, we used a corneal epithelial cell culture system from corneal explant outgrowths (24). The migrating cells formed in the epithelial cell culture resembled native corneal epithelial cells (Fig. 1). Cells migrating from the explants expressed p53 protein in their cytoplasm and demonstrated positive staining with Mab-421, negative staining with Mab-248 and negative p53 staining with a monoclonal antibody against phosphorylated Ser15 (Fig. 2 and Table II). Corneal epithelial cells positive for cytoplasmic p53 staining were noted to be with and without MitoTracker uptake and mitochondrial staining (Fig. 3A and B). Cells with negative Mab-421 staining also demonstrated punctuate labeling corresponding to MitoTracker uptake by mitochondria (Fig. 3C). From 30 min until $24 \mathrm{~h}$ following UV irradiation, p53 translocated to the nucleus when compared to the control cells without p53 staining in the nucleus (Fig. 4A).

p53 staining in the corneal epithelial cells was rapidly altered following UV illumination. Positive cytoplasmic p53 staining with Mab-248 and the Mab against phosphorylated Ser15 was noted within 30 min following UV exposure (Table II). p53 staining with Mab-421 was intensified following UV illumination, peaking at $2 \mathrm{~h}$ and returning to a level lower than that of the control within $24 \mathrm{~h}$ after UV treatment (Fig. 5). Apoptosis, as measured by TUNEL staining, was intensified after UV illumination and peaked within $6 \mathrm{~h}$ following 

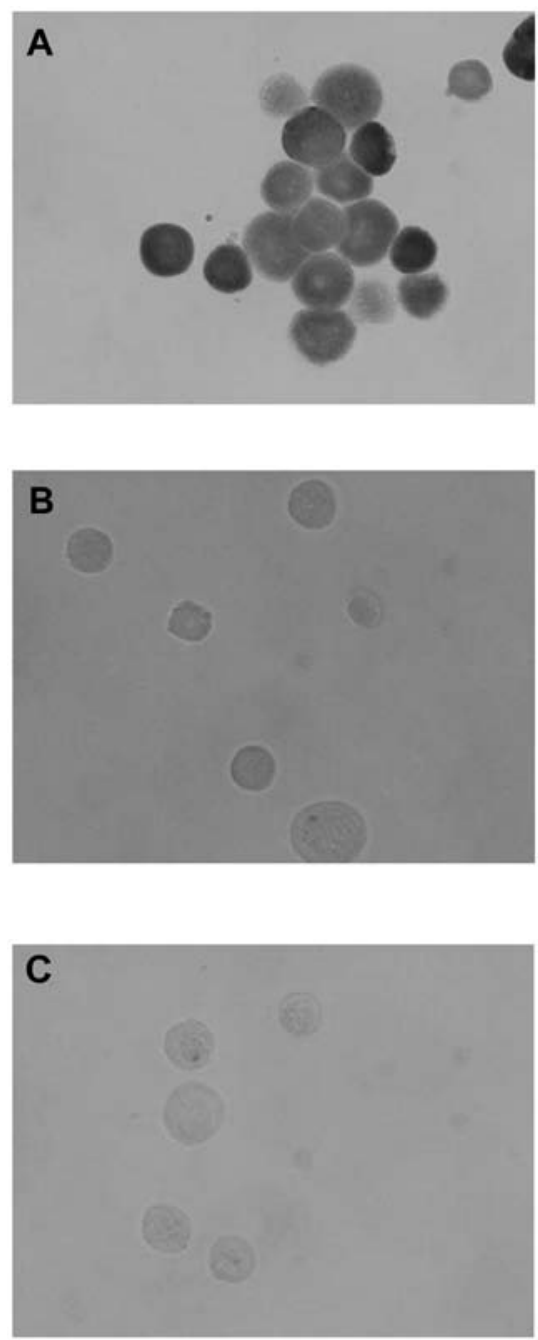

Figure 2. Cultured corneal cells demonstrated (A) cytoplasmic staining with Mab-421, (B) negative staining with Mab-248, and (C) negative staining with anti-phosphorylated Ser15.

UV treatment (Fig. 6). Addition of pifithrin- $\alpha$ (a reversible inhibitor of p53-mediated apoptosis and p53-dependent gene transcription) did not alter apoptosis in the control cells, but did decrease apoptosis of the UV-irradiated cells. The apoptotic index (AI) was decreased by pifithrin; the maximal decrease occurred $24 \mathrm{~h}$ after UV irradiation (Table II).

Western blot analysis. To confirm our in situ staining data, western blot analysis was performed. The western blot analysis (Fig. 7) corroborated the results of the p53 staining of the mouse corneal epithelial cells. Specifically, p53 protein levels reached a maximum $2 \mathrm{~h}$ after $\mathrm{UV}$ irradiation $(\mathrm{P}<0.001)$ and decreased only after $24 \mathrm{~h}$, without being reduced below unirradiated control levels (Fig. 7).

Quantitative p53 mRNA determination. To assess whether the UV-induced p53 regulation occurred at the RNA level, real-time PCR was carried out on UV-irradiated tissue. p53 mRNA levels following UV irradiation of the mouse corneal epithelium were not significantly changed as compared with control (Fig. 8).
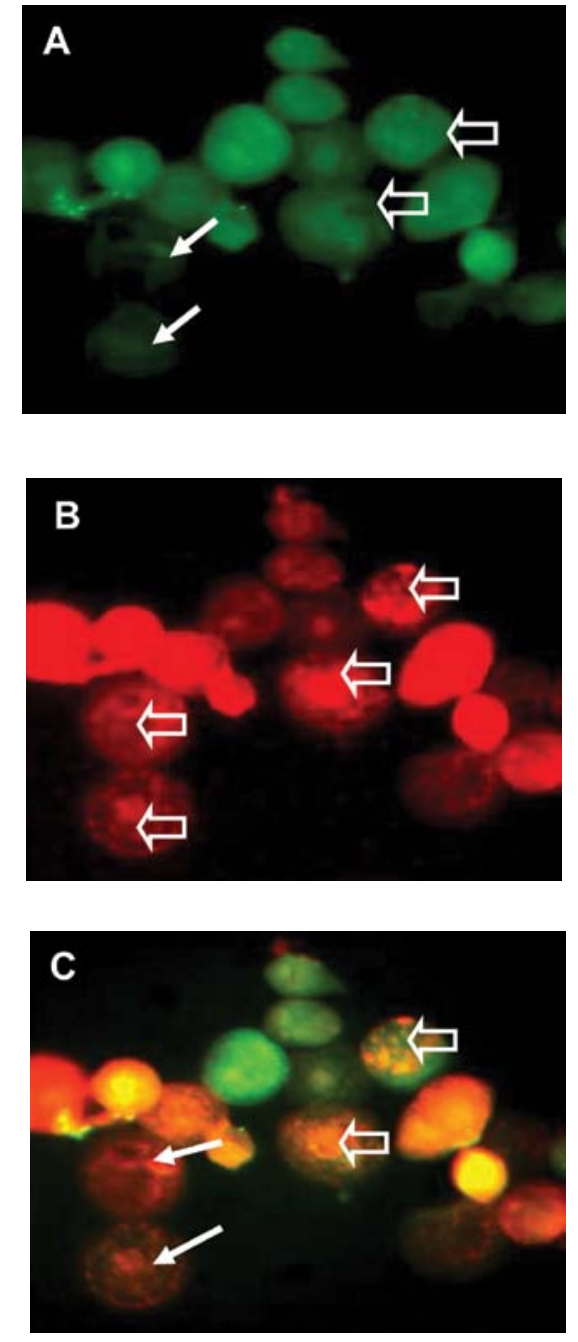

Figure 3. Confocal images of cultured corneal epithelial cells using p53 staining (green) with anti-p53 antibody Mab-421 (second a/b FITC conjugated) and MitoTracker Red 580. (A) Open arrows indicate cells with cytoplasmic 553 staining and solid arrows indicate cells without cytoplasmic p53 staining (green). (B) Open arrows indicate cells with red punctuate staining corresponding to Mitotracker uptake by mitochondria. (C) Overlaid image of A and B shows punctuate staining corresponding to Mitotracker uptake by mitochondria with (open arrows) and without (solid arrows) green cytoplasmic p53 staining. Magnification, x600.

\section{Discussion}

In the present study, we demonstrated the presence of p53 in the cytoplasm of cultured primary corneal epithelial cells. This result was identical to previous results noted in intact corneal epithelia in rats (18), mice (20) as well as in other species (19). Hence, the in vitro tissue culture model for p53 expression as described in the present study may truly represent what occurs in vivo for p53 expression in the cornea. We demonstrated, in the corneal epithelial cells, that a nuclear translocation of cytoplasmic p53, occurred following UV irradiation. Moreover, the UV irradiation under the same condition induced epithelial cell apoptosis as measured by TUNEL staining. UV-induced p53 nuclear translocation did not appear to be regulated by transcriptional mechanisms.

We previously reported that the $\mathrm{p} 53$ protein is strongly expressed in normal vertebrate adult corneal epithelium (19). 

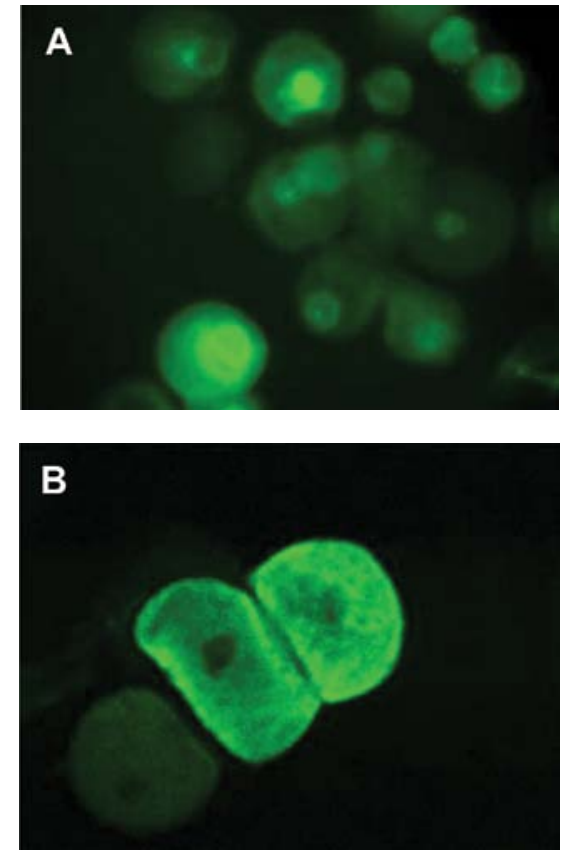

Figure 4. Confocal microscope image of $\mathrm{p} 53$ translocation to the nucleus in cultured corneal epithelial cells, using Mab-421 to stain p53: (A) $2 \mathrm{~h}$ after UV irradiation and (B) control cells. Magnification, x600.

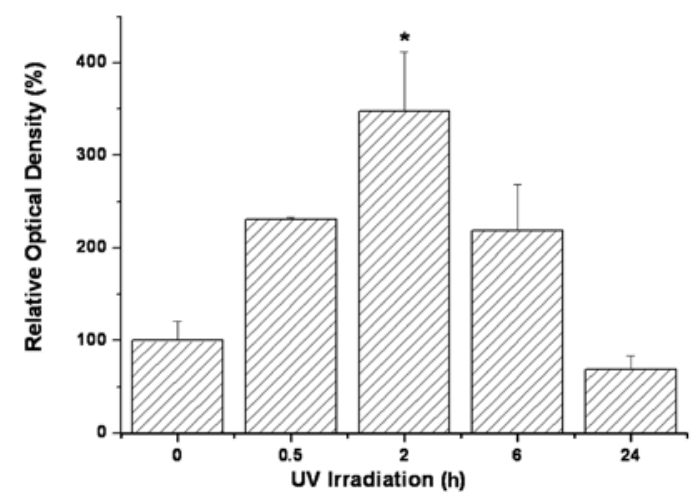

Figure 5. Quantification of the optical density of p53 staining in cultured corneal epithelial cells with Mab-421 as a function of the duration of UV irradiation. Kruskal-Wallis nonparametric ANOVA analysis, $\mathrm{P}<0.005$ with $\mathrm{n}>11$. Dunn's post hoc analysis, ${ }^{\mathrm{P}}<0.05$.

In that previous study, immunostaining of frozen eye sections, similar to the cultured corneal epithelium in the present study, did not show $\mathrm{p} 53$ immunostaining for all of the p53 Mabs used, while western blot analysis was positive for all antibodies used. We suggested that several p53-binding proteins may compete for antibody epitope sites and hence block certain 'non-staining' p53 Mabs.

We found differential staining of Mab-421 and Mab-248 on the immunohistochemical preparations and identical positive staining of these same antisera upon western blot analysis of corneal epithelial cell protein extracts. Similar data were obtained in our previous studies in vivo $(19,20)$. The antibody Mab-248 binds to an N-terminal $(3,25,26)$ or central $(27)$ epitope of p53, while Mab-421 binds to a C-terminal epitope $(26,28)$. The non-reactivity of Mab-248 in native corneal and conjunctival epithelium, as noted using immunohistochemical
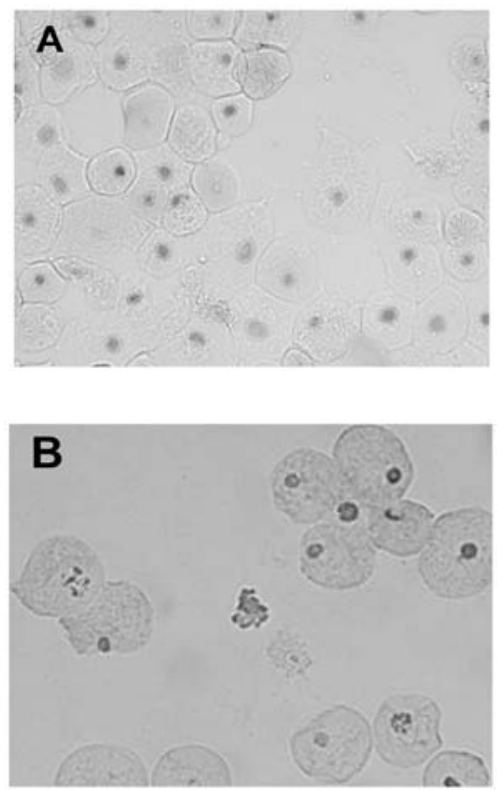

Figure 6. TUNEL staining of corneal epithelial cells (A) without UV irradiation and (B) $6 \mathrm{~h}$ after UV irradiation. Magnification, $\mathrm{x} 400$.

A

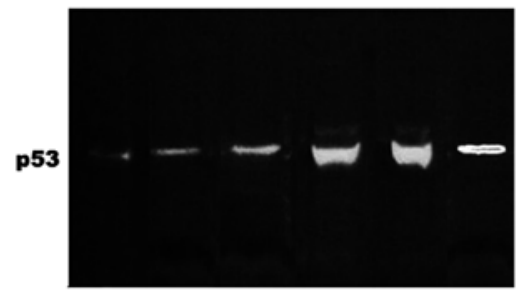

B

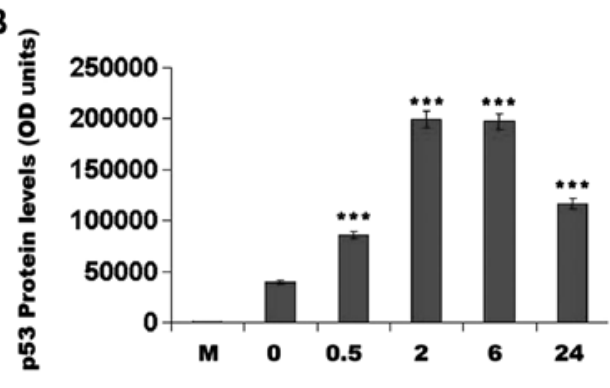

Time after Irradiation (h)

Figure 7. Western blot analysis and quantification of p53 protein expression in cultured corneal epithelial cells with Mab-248 as a function of the UV irradiation duration. (A) Representative western blot. (B) Cumulative results. M, p53-positive control; $\mathrm{n}=4$; ANOVA, $\mathrm{P}<0.0001$; post hoc, ${ }^{* * * *} \mathrm{P}<0.001$ with respect to no irradiation.

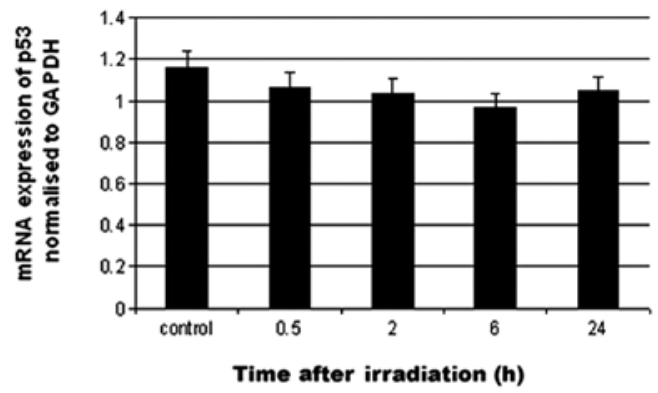

Figure 8. Real-time PCR p53 mRNA expression in cultured mouse corneal epithelial cells as a function of the UV irradiation duration. 
techniques, may indicate the presence of an N-terminal or central region p53 binding protein, such as $\alpha \mathrm{B}$-crystallin. $\alpha \mathrm{B}$-crystallin interacts with p53 in the cytoplasm of cells (33), hence covering a putative antibody epitope. The limbo-corneal epithelium constitutively expresses $\alpha \mathrm{B}$-crystallin with higher levels in the proliferative compartment (34). Upon denaturation, as occurs in western blotting, any protein binding noncovalently to p53 would thus be removed from its binding site, so that all the internal p53 epitopes become exposed (20). This would explain the differential Mab reactivity noted by immunohistochemistry and the apparent equal reactivity of these same monoclonal antibodies upon western blot analysis.

The regulation of p53 activity is mainly post-translational. Stabilization is an essential step for p53 to function efficiently in response to UV irradiation. This study demonstrated that UV irradiation of corneal epithelium cultures induced cytoplasmic p53 phosphorylation within $30 \mathrm{~min}$. Until p53 appeared in the nucleus, we noted an increase in apoptosis that may have been caused by the original cytoplasmic p53 protein. The cytoplasmic p53 protein of the corneal epithelium may participate in transcriptional- and mitochondrial-dependent apoptotic pathways, as it is always present in the corneal epithelium cytoplasm (20).

There have been reports of an 'inactive' p53 isoform found in the cytoplasm (35). In the present study we also found large amounts of cytoplasmic p53 in cultured rodent corneal epithelium. This may represent examples of transitory 'inactive' p53. Upon UV irradiation, rapid phosphorylation of cytoplasmic p53 may clear damaged cells by inducing apoptosis (36). This is consistent with the rapid transit of cytoplasmic p53 protein into the nucleus upon UV irradiation and suggests the presence of an active p53 form in the cytoplasm. We found that p53 transcriptional activity was not significantly altered by UV irradiation. We, therefore, suggest that the increase in the p53 protein after UV irradiation is the result of post-translational stabilization. A similar observation was noted by others in the human epidermis $(8,37)$.

In order to clearly understand how p53 functions in regulating the cell cycle, it is important to identify all of its possible functions and all of the proteins interacting with it. The present study demonstrated the existence of functionally active cytoplasmic p53 protein in normal cultured rodent corneal epithelium cells. Additional studies are warranted to fully characterize the role of the p53 protein and its regulation as part of its physiological function in normal corneal epithelium.

\section{Acknowledgements}

We thank Professor Varda Rotter and Dr Naomy Goldfinger (Weizman Institute of Science, Rehovot, Israel) for kindly providing the Mabs-421 and -248 as well as the p53-positive control, p53-M clone 314 cell extract. We also would like to thank Drs Elvira Bormusov and Aviva Lazarovich (Technion, Haifa, Israel) for their technical assistance and Ms. Judith Rondel for the critical reading of our manuscript. We would also like to acknowledge grant support for this study to Y.T. and A.P. from the Center for Immigrant Scientist Absorption of the Ministry of Absorption, State of Israel as well as to Y.T. and G.W. from the Edward S. Mueller Eye Research Fund, Israel.

\section{References}

1. Linzer DI and Levine AJ: Characterization of a 54K Dalton cellular SV40 tumor antigen present in SV40-transformed cells and unifected embryonal carcinoma cells. Cell 17: 43-52, 1979.

2. Lane DP: Cancer. p53, guardian of the genome. Nature 358: 15-16, 1992.

3. Lane DP, Stephen CW, Midgley CA, Sparks A, Hupp TR, Daniels DA, Greaves R, Reid A, Vojtesek B and Picksley SM: Epitope analysis of the murine p53 tumour suppressor protein. Oncogene 12: 2461-2466, 1996

4. Kastan MB, Onyekwere O, Sidransky D, Vogelstein B and Craig RW: Participation of $\mathrm{p} 53$ protein in the cellular response to DNA damage. Cancer Res 51: 6304-6311, 1991.

5. Hartwell L: Defects in a cell cycle checkpoint may be responsible for the genomic instability of cancer cells. Cell 71: 543-546, 1992.

6. Unger T, Nau MN, Segal S and Minna JD: p53: a transdominant regulator of transcription whose function is ablated by mutations occurring in human cancer. EMBO J 11: 1383-1390, 1992.

7. Clarke AR, Purdie CA, Harrison DJ, Morris RG, Bird CC, Hooper ML and Wyllie AH: Thymocyte apoptosis induced by p53-dependent and -independent pathways. Nature 362: 849-852, 1993.

8. Hall PA, Mckee PH, Du P, Manage H, Dover R and Lane DP: High levels of $\mathrm{p} 53$ protein in UV-irradiated normal human skin. Oncogene 8: 203-207, 1993.

9. Hall PA and Lane DP: Tumour supressors: a developing role for p53? Curr Biol 7: R144-R147, 1997.

10. Teodoro JG, Evans SK and Green MR: Inhibition of tumor angiogenesis by p53: a new role for the guardian of the genome. J Mol Med 85: 1175-1186, 2007.

11. Sah VP, Attardi LD, Mulligan GJ, Williams BO, Bronson RT and Jacks T: A subset of p53-deficient embryos exhibit exencephaly. Nat Genet 10: 175-180, 1995.

12. Matoba S, Kang JG, Patino WD, Wragg A, Boehm M, Gavrilova O, Hurley PJ, Bunz F and Hwang PM: p53 regulates mitochondrial respiration. Science 312: 1650-1653, 2006.

13. Erster S and Moll UM: Stree-induced p53 runs a transcriptionindependent death program. Biochem Biophys Res Commun 331: 843-850, 2005

14. Mihara M, Erster S, Zaika A, Petrenko O, Chittenden T, Pancoska P and Moll UM: p53 has a direct apoptogenic role at the mitochondria. Mol Cell 11: 577-590, 2003.

15. Chipuk JE, Kuwana T, Bouchier-Hayes L, Droin NM, Newmeyer DD, Schuler M and Green DR: Direct activation of Bax by p53 mediates mitochondrial membrane permeabilization and apoptosis. Science 303: 1010-1014, 2004.

16. Murphy ME, Leu JI and George DL: p53 moves to mitochondria: a turn on the path to apoptosis. Cell Cycle 3: 836-839, 2004.

17. Bonini P, Cicconi S, Cardinale A, Vitale C, Serafino AL, Ciotti MT and Marlier LN: Oxidative stress induces p53-mediated apoptosis in glia: p53 transcription-independent way to die. J Neurosci Res 75: 83-95, 2004.

18. Tendler Y, Weisinger G, Coleman R, Diamond E, Lischinsky S, Kerner H, Rotter V and Zinder O: Tissue-specific p53 expression in the nervous system. Brain Res Mol Brain Res 72: 40-46, 1999.

19. Tendler Y, Panshin A, Weisinger G and Zinder O: Identification of cytoplasmic p53 protein in corneal epithelium of vertebrates. Exp Eye Res 82: 674-681, 2006.

20. Pokroy R, Tendler Y, Pollack A, Zinder O and Weisinger G: p53 expression in the normal murine eye. Invest Ophthalmol Vis Sci 43: 1736-1741, 2002.

21. Estil S, Kravik K, Haaskjold E, Refsum SB, Bjerknes R and Wilson G: Pilot study on the time course of apoptosis in the regenerating corneal epithelium. Acta Ophthalmol Scand 80: $517-523,2002$.

22. Ren H and Wilson G: The effect of ultraviolet-B irradiation on the cell shedding rate of the corneal epithelium and changes of p53 expression. Acta Ophthalmol 72: 447-452, 1994.

23. Ren H and Wilson G: Apoptosis in the corneal epithelium. Invest Ophthalmol Vis Sci 37: 1017-1025, 1996.

24. Lomako J, Lomako WM, Decker SJ, Carraway CA and Carraway KL: Non-apoptotic desquamation of cells from corneal epithelium: putative role for Muc4/sialomucin complex in cell release and survival. J Cell Physiol 202: 115-124, 2005.

25. Wade-Evans A and Jenkins JR: Precise epitope mapping of the murine transformation-associated protein, p53. EMBO J 4: 699-706, 1985. 
26. Yewdell JW, Gannon JV and Lane DP: Monoclonal antibody analysis of p53 expression in normal and transformed cells. J Virol 59: $444-452,1986$.

27. Yin X, Fontoura B, Morimoto T, Robert B and Carroll RB: Cytoplasmic complex of p53 and eEF2. J Cell Physiol 196: 474-482, 2003.

28. Arai N, Nomura D, Yokota K, Wolf D, Brill E, Shohat O and Rotter V: Immunologically distinct p53 molecules generated by alternative splicing. Mol Cell Biol 6: 3232-3239, 1986.

29. Gavrieli Y, Sherman Y and Ben-Sasson SA: Identification of programmed cell death in situ via specific labelling of nuclear DNA fragmentation. J Cell Biol 119: 493-501, 1992.

30. Bradford MM: A rapid and sensitive method for the quantitation of microgram quantities of protein utilizing the principle of protein-dye binding. Anal Biochem 72: 248-254, 1976.

31. Sambrook J, Fritsch EF and Maniatis T: Molecular Cloning: A Laboratory Manual. 2nd edition, Cold Spring Harbor Laboratory Press, New York, pp1834-1874, 1989.

32. Almog N, Li R, Peled A, Schwartz D, Wolkowicz R, Goldfinger N, Pei $\mathrm{H}$ and Rotter V: The murine $\mathrm{C}^{\prime}$-terminal alternatively spliced form of p53 induces attenuated apoptosis in myeloid cells. Mol Cell Biol 17: 713-722, 1997.
33. Liu S, Li J, Tao Y and Xiao X: Small heat shock protein alphaB-crystallin binds to 53 to sequester its translocation to mitochondria during hydrogen peroxide-induced apoptosis. Biochem Biophys Res Commun 354: 109-114, 2007.

34. Grueterich M, Alge C, Fuchs A, Kampik A and Welge-Luessen U: Alpha-B-crystallin in the limbal and corneal epithelium. Invest Ophthalmol Vis Sci 44E: 1358, 2003.

35. Shaulsky G, Goldfinger N, Tosky M, Levine AJ and Rotter V: Nuclear localization is essential for the activity of $\mathrm{p} 53$ protein. Oncogene 6: 2055-2065, 1991.

36. Bean LJ and Stark GR: Phosphorylation of serines 15 and 37 is necessary for efficient accumulation of $\mathrm{p} 53$ following irradiation with UV. Oncogene 20: 1076-1084, 2001.

37. Qin JZ, Chaturvedi V, Denning MF, Bacon P, Panella J, Choubey D and Nickoloff BJ: Regulation of apoptosis by p53 in UV-irradiated human epidermis, psoriatic plaques and senescent keratinocytes. Oncogene 21: 2991-3002, 2002. 